\title{
Analisis Pengaruh Kebijakan Pembelajaran Jarak Jauh (PJJ) Akibat Dampak Pandemik Covid-19 Terhadap Motivasi Belajar Peserta Didik
}

\author{
Indri Septiani, Palupi Lindiasari Samputra \\ Ketahanan Nasional SKSG, Universitas Indonesia
}

\begin{abstract}
ABSTRAK
Penelitian ini bertujuan untuk 1) Mengetahui perbedaan metode pembelajaran Ceramah Plus dan metode pembelajaran Discovery Learning terhadap hasil belajar peserta didik, keaktifan peserta didik dalam bertanya, pengumpulan tugas peserta didik dan kehadiran peserta didik dalam belajar pada saat PJJ, 2) Menganalisis efektifitas metode pembelajaran yang digunakan untuk meningkatkan motivasi belajar peserta didik pada saat PJJ, 3) Menganalisis strategi metode pembelajaran dalam meningkatkan motivasi belajar peserta didik pada saat PJJ. Jenis penelitian ini quasi experiment. Populasi penelitian adalah sebanyak 50 siswa dilakukan secara purposive sampling. Sampel penelitian merupakan sampel yang sama dengan dua perlakuan. Data yang diperoleh dianalisis serta diuji dengan statistik Uji Sign Test. Hasilnya sebagai berikut, 1) Terdapat perbedaan antara nilai hasil ulangan, daftar kehadiran, keaktifan bertanya, dan pengumpulan tugas dengan menggunakan metode belajar Ceramah Plus dan Discovery Learning, 2) Kedua metode belajar tersebut memiliki kefektifan masing-masing saat diterapkan, Ceramah Plus lebih efekif dalam kehadiran dan keaktifan bertanya sedangkan Discovery Learning lebih efektif dalam meningkatkan nilai hasil ulangan dan pengumpulan tugas sedangkan 3) Metode Discovery Learning merupakan metode yang paling baik untuk meningkatkan motivasi belajar peserta didik pada saat PJJ.
\end{abstract}

Kata Kunci: Discovery learning, ceramah plus, pembelajaran jarak jauh

\section{PENDAHULUAN}

Pendidikan sangat penting dalam proses pembangunan manusia, tolak ukur pembangunan manusia sendiri salah satunya adalah pemberdayaan yaitu dengan meningkatkan kemampuan fisik penduduk seperti kesehatan dan pendidikan (Wan Usman, 2003: 189-190). Terciptanya pendidikan yang baik akan melahirkan sumber daya manusia yang berkualitas yang tidak hanya memiliki kepintaran hardskill (kecerdasan intelektual) melainkan juga memiliki softskill (keterampilan). Hal tersebut juga merupakan salah satu bentuk usaha dalam membangun ketahanan individu untuk mewujudkan ketahanan nasional. Tujuan pendidikan nasional menurut Undang-undang Nomor 20 Tahun 2003 tentang Sistem Pendidikan Nasional, Pasal 3 menyebutkan bahwa tujuan pendidikan nasional adalah mengembangkan potensi peserta didik agar menjadi manusia yang beriman dan bertakwa kepada Tuhan Yang Maha Esa, berakhlak, mulia, sehat, berilmu, cakap, kreatif, mandiri, dan menjadi warga negara yang demokratis serta bertanggung jawab. Sejalan dengan capaian pembelajaran pada kurikulum 2013 yang digunakan oleh SMA Labschhol Kebayoran, bahwa proses pembelajaran harus mencakup kualifikasi sikap, pengetahuan dan keterampilan peserta didik, yang dijabarkan ke dalam masing-masing kompetensi inti sesuai dengan Permendikbud N0. 54 tentang Standar Kompetensi Lulusan. Dapat disimpulkan bahwa pendidikan bukan hanya sekedar sarana meningkatkan kemampuan kecerdasan otak peserta didik melainkan juga harus mampu mengembangkan kemampuan lainnya seperti keaktifan dan kreatifitas peserta didik. 
Pada pertengahan bulan februari 2020, Indonesia diserang oleh wabah virus pandemik yang dikenal dengan sebuatan Covid-19 dan telah ditetapkan sebagai bencana nasional. Data sampai tanggal 29 Oktober 2020 yang dilansir dari laman daring Kementerian Kesehatan, tercatat sebanyak 404.048 orang positif dan 13.701 orang dinyatakan meninggal karena wabah ini. Cara penularan virus ini sangat mudah dan cepat melalui cipratan air ludah, kontak erat, serta memegang benda yang terdapat virus (Kemenkes RI, 2020). Sehingga masyarakat tidak diperkenankan untuk melakukan kerumunan. Dampak bencana Covid-19 berpengaruh besar terhadap tatanan negara dan masyarakat, termasuk di bidang pendidikan dan secara langsung merubah cara pembelajaran disekolah. Berdasarkan Surat Edaran dari Dinas Pendidikan Provinsi Daerah Khusus Ibukota Jakarta atas arahan Gubernur (SE No.27/SE 2020 Tentang Pembelajaran di Rumah). Dalam upaya pencegahan dan penyebaran virus, SMA Labscool Kebayoran mengambil kebijakan untuk melaksanakan pembelajaran jarak jauh (atau yang dikenal dengan sebutan PJJ).

Pembelajaran jarak jauh telah banyak mengubah cara pembelajaran baik dari sisi pengajar, metode pembelajaran maupun dari sisi murid. Adapun yang berubah adalah pembelajaran yang semula dilakukan secara tatap muka berubah menjadi pembelajaran berbasis daring, perubahan jadwal jam mengajar, perubahan rombongan kelas belajar, sampai kepada penyusunan ulang agenda-agenda akademik dan kesiswaan yang telah terjadwal. PJJ juga menyebabkan dampak negatif dan positif dalam pembelajaran. Dampak negatif-nya antara lain; 1) Guru dan peserta didik yang tidak biasa melakukan sistem pembelajaran secara daring akan sangat mengalami kesulitan, 2) Akses dan sinyal internet akan menjadi penghambat terbesar dalam proses pembelajaran, dan 3) Guru akan lebih sulit melakukan pemantauan terhadap murid dalam proses belajar, dan 4) Capaian belajar berdasarkan kurikulum 2013 tidak dapat tercapai secara maksimal. Adapun dampak Positif dari PJJ antara lain; 1) Guru dan peserta didik lebih familiar terhadap teknologi berbasis daring, 2) Ilmu pengetahuan diterima oleh murid akan lebih banyak dan bervariasi, dan 4) Guru dituntut lebih kreatif dalam menyajikan metode pembelajaran kepada murid.

Dari dampak negatif diatas, maka hal yang paling ditakutkan adalah penurunan motivasi belajar yang terjadi pada peserta didik. Menurut (Hamzah B. Uno, 2011) hakikat motivasi belajar adalah dorongan internal dan eksternal pada peserta didik-peserta didik yang sedang belajar untuk mengadakan perubahan tingkah laku, pada umumnya dengan beberapa indikator atau unsur yang mendukung. Berdasarkan data observasi yang dilakukan dalam mata pelajaran PPKN kelas X pada rentang waktu satu minggu pemberlakuaan sistem pembelajaran dari rumah, terjadi penurunan keaktifan anak sebesar $45 \%$ yang dinilai dari banyaknya anak merespon guru dengan bertanya dan penurunan sebesar 14\% terhadap kehadiran di dalam kelas. Jika pada saat pembelajaran tatap muka keaktifan anak dalam bertanya bisa mencapai $65 \%$, maka pada saat pembelajaran PJJ keatifan anak hanya mencapai $15 \%$. Sedangkan, untuk kehadiran dalam kelas pada saat tatap muka bisa mencapai $94 \%$, namun ketika PJJ hanya mencapai $80 \%$.

Hal tersebut tidak dapat dibiarkan secara berlarut, jika capaian pembelajaran pada kurikulum 2013 ingin tetap diwujudkan dalam pembelajaran jarak jauh. Untuk itu, guru dan sekolah harus segera membuat strategi dan rumusan agar kegiatan belajar mengajar dapat berjalan dengan kondusif. Dalam merespon adanya indikasi penurunan motivasi belajar, SMA Labschool Kebayoran melakukan hal-hal sebagai berikut: 1) Mengelompokan peserta didik sesuai dengan capaian nilai dan keaktifan dalam kelas, 2) Mewajibkan koordinasi antara guru mata pelajaran dan wali kelas tentang kekurangan hasil belajar anak, 3) mewajibkan koordinasi antara wali kelas dengan orang tua peserta didik tentang keikutsertaan anak dalam PJJ, 4) Ikut melibatkan orang tua peserta didik dalam proses 
pemantauan dan pengawasan selama PJJ, 5) Mengatur ulang jam pelajaran dan memasukan jadwal untuk berjemur dalam proses pembelajaran setiap hari. 6) Melakukan pelatihanpelatihan pembelajaran berbasis daring kepada seluruh guru pengajar. Sedangkan untuk metode pembelajaran, pihak sekolah menyerahkan kepada masing-masing guru mata pelajaran dengan tetap memperhatikan capaian pembelajaran dalam kurikulum 2013.

Untuk itu, dalam penelitian ini metode pembelajaran yang digunakan oleh guru PPKN Kelas X SMA Labschool Kebayoran selama pembelajaran tatap muka adalah metode pembelajaran Ceramah Plus. Metode ini merupakan metode yang umum dipakai oleh pengajar yaitu metode dengan menggabungkan penyampaian materi, diskusi dan Tanya jawab. Sedangkan yang diterapkan selama pembelajaran jarak jauh adalah metode pembelajaran Discovery Learning. Metode Discovery Learning dipilih dalam PJJ, dikarenakan metode ini dirasa tepat digunakan di tengah kondisi dampak Covid-19, dengan metode ini, peserta didik dituntut agar lebih aktif mempelajari materi yang diberikan, serta dituntut untuk mencari jawaban dari permasalahan yang berkaitan dengan materi secara mandiri. Terlebih, tujuan belajar PPKN salah satunya adalah untuk menjadi warga negara yang baik, serta muatan-muatan materi PPKN sangat berkaitan erat dengan lingkungan masyarakat dan Negara, seperti materi yang sedang di pelajari dengan menggunakan metode ini adalah materi Wawasan Nusantara. Oleh karena itu, diharapkan dengan metode Discovery Learning, peserta didik mampu menganalisis dan memecahkan masalah yang ada disekitarnya khususnya masalah-masalah terkait Covid-19. Untuk media yang dipilih adalah media $E$ learning dengan menggunakan aplikasi Google-meet sebagai media penyampaian materi, aplikasi Quizziz untuk pengambilan nilai kuis maupun ulangan harian, aplikasi Instagram untuk mengambil nilai keterampilan. Metode belajar ini akan diterapkan selama pembelajaran jarak jauh guna mengetahui ke-efektifannya dalam meningkatkan motivasi belajar anak.

Penelitian sebelumnya terkait metode Discovery Learning yang dilakukan oleh Hasugian (2013), Sulfemi (2019), Mashuri (2019), Utami (2019), Hutapea (2019), Farida, Suani, dan Zulkardi (2019), Ananta, Zulkarnain, Yenita (2019), menemukan bahwa metode Discovery Learning dapat meningkatkan hasil belajar peserta didik. Sementara penelitian lain yang dilakukan oleh Iin Kartikasari (2012) menemukan adanya pengaruh langsung dan positif terhadap motivasi belajar dan hasil belajar peserta didik, Khaeruman dan Muhammad Saleh (2016) menemukan peserta didik memiliki rasa percaya diri lebih baik. Suhartatik (2020) menemukan peningkatan sikap disiplin dan hasil belajar pada peserta didik, Dewi, Zahara, Handoko (2019) menemukan terdapat peningkatan kemampuan penalaran logis terhadap peserta didik. Muthmainah dan Sumarsih (2019) menemukan bahwa penerapan model pembelajaran discovery learning dapat mengurangi tingkat kecemasan siswa, dan penelitian yang dilakukan oleh Dani, Latifah dan Putri (2019) menemukan peningkatan pemahaman konsep belajar peserta didik dengan penerapan metode Discovery Learning.

Berdasarkan dari teori, hasil observasi dan penelitian terdahulu, penulis sangat yakin bahwa penelitian yang akan dilakukan oleh penulis belum pernah dilakukan oleh penelitian sebelumnya. Dikarenakan dalam penelitian ini, penulis akan menggunakan dua metode pembelajaran untuk meningkatkan motivasi belajar dengan lebih dari satu variabel operasional, yang diterapkan dalam keadaan khusus pada masa pandemik Covid-19. Adapun tujuan penelitian ini adalah untuk; 1) Mengetahui perbedaan metode pembelajaran Ceramah Plus dan metode pembelajaran Discovery Learning terhadap hasil belajar peserta didik, keaktifan peserta didik dalam bertanya, pengumpulan tugas peserta didik dan kehadiran peserta didik dalam belajar pada saat PJJ, 2) Menganalisis efektifitas metode pembelajaran yang digunakan untuk meningkatkan motivasi belajar peserta didik pada saat PJJ, 3) 
Menganalisis strategi metode pembelajaran dalam meningkatkan motivasi belajar peserta didik pada saat PJJ.

\section{METODE PENELITIAN}

Metode yang digunakan dalam penelitian ini adalah metode eksperimen. Tujuan dari penelitian eksperimen adalah untuk menyelediki ada tidaknya hubungan sebab akibat serta berapa besar hubungan sebab akibat tersebut dengan cara memberikan perlakukan-perlakuan tertentu pada beberapa kelompok eksperimen dan menyediakan kontrol untuk perbandingan (Simone Colombo, dkk, 2014). Bentuk penelitian ini berupa post-test terhadap kelompok eksperimen untuk mengetahui hasil belajar, kehadiran, keaktifan bertanya dan banyaknya pengumpulan tugas yang dilakukan oleh peserta didik selama pembelajaran jarak jauh. Populasi dalam penelitian ini adalah seluruh peserta didik kelas X SMA Labschool Kebayoran Tahun Ajaran 2020/2021 dengan total jumlah peserta didik 276 orang. Sedangkan kelas sampel yang diambil berjumlah 50 orang dengan tenik purposive sampling. Prosedur yang dilaksakan dalam menerapkan desain penelitian ini adalah menentukan kelas yang akan dijadikan sebagai kelompok eksperimen. Sampel yang digunakan merupakan sampel yang sama dengan dua perlakuan yang berbeda, yakni peserta didik pada saat diberikan metode belajar ceramah plus dan peserta didik ketika diberikan metode belajar discovery learning, mengadakan posttest pada masing-masing kelompok untuk mengetahui pengaruh dari perlakuan pengajaran yang telah diberikan. Teknik uji statistik yang digunakan adalah $U j i$ Sign Test (dependent) - Non Parametrik. Jika $\mathrm{H}_{0}<0,05$ maka terdapat berbedaan terhadap dua perlakuan.

\section{HASIL DAN PEMBAHASAN}

\section{Pembelajaran Jarak Jauh}

Pembelajaran Jarak Jauh menurut beberapa ahli didefiniskan sebagai Pendidikan formal (resmi) berbasis institusi/ lembaga dimana kelompok belajar (rombel) yang secara terpisah menggunakan sistem telekomunikasi interaktif untuk menghubungkan antara peserta didik, pendidik, dan sumber belajar. (Simonson, dalam Estu Miyarso 2010). PJJ sebagai bagian dari metode pembelajaran dimana perilaku mengajar dieksekusi terpisah dari perilaku belajar, termasuk yang dilakukan di hadapan peserta didik, sehingga komunikasi antara guru dan guru - pelajar harus difasilitasi dengan alat cetak, elektronik, mekanik, atau lainnya. (Michael Moore dalam Estu Miyarso, 2020). Berdasarkan Desmond Keegan (Estu Miyarso, 2020) mengidentifikasi lima elemen utama PJJ : 1) Pemisahan guru dan pelajar (bukan tatap muka), 2) Melibatkan lembaga dalam mengorganisasi dan mengelola program pendidikan, 3) Penggunaan media teknis-cetak, audio, video, atau komputer-untuk menyatukan guru peserta didik., 4) Penyediaan komunikasi dua arah guru -peserta didik Tidak adanya absennya kelompok belajar, 5) Proses belajar secara perorangan dan sesekali secara klasikal (tatap muka). Dari beberapa definisi tersebut, PJJ dapat diartikan sebagai proses pembelajaran yang dilakukan dalam satuan pendidikan yang memisahkan ruang dan waktu antara guru dan peserta didik dengan menggunakan metode dan media tertentu.

\section{Motivasi Belajar}

Motivasi berasal dari kata motif yang berarti dorongan yang terarah kepada pemenuhan psikis dan rokhaniah. Menurut Mc. Donald (Oemar Hamalik, 2011), motivasi adalah perubahan energi dalam diri (pribadi) seseorang yang ditandai dengan timbulnya perasaan dan reaksi 
untuk mencapai tujuan. Sedangkan menurut (Sardiman A. M, 2010) dalam kegiatan belajar motivasi dapat dikatakan sebagai keseluruhan daya penggerak di dalam diri siswa yang menimbulkan kegiatan belajar, sehingga tujuan yang dikehendaki oleh subjek belajar itu dapat tercapai. Menurut (M. Dalyono ,2009) motivasi belajar adalah suatu daya penggerak atau dorongan yang dimiliki oleh manusia untuk melakukan suatu pekerjaan yaitu belajar. Menurut (Hamzah B. Uno, 2011) hakikat motivasi belajar adalah dorongan internal dan eksternal pada siswa-siswa yang sedang belajar untuk mengadakan perubahan tingkah laku, pada umumnya dengan beberapa indikator atau unsur yang mendukung. Iindikator motivasi belajar dapat diklasifikasikan sebagai berikut: 1) Adanya hasrat dan keinginan berhasil, 2) Adanya dorongan dan kebutuhan dalam belajar, 3) Adanya harapan atau cita-cita masa depan , 4) Adanya penghargaan dalam belajar, 5) Adanya kegiatan yang menarik dalam belajar, 6) Adanya lingkungan belajar yang kondusif, sehingga memungkinkan seorang siswa dapat belajar dengan baik.

Berdasarkan uraian tersebut dapat disimpulkan pengertian motivasi belajar yaitu keseluruhan daya penggerak atau dorongan di dalam diri siswa untuk melakukan kegiatan belajar yang ditandai perubahan energi untuk mencapai tujuan yang dikehendaki. Ciri-ciri motivasi belajar yang tinggi timbul dapat dilihat dari ketekunan dalam dirinya dalam mengerjakan tugas, tidak putus asa jika menghadapi kesulitan, tertarik terhadap bermacam masalah dan memecahkannya, senang bekerja mandiri, bosan terhadap tugas rutin, dapat mempertahankan pendapat, dan tidak mudah melepaskan hal yang diyakini. Motivasi belajar juga dapat didorong dengan adanya penghargaan, kegiatan yang menarik, dan lingkungan yang kondusif dalam belajar. Seorang siswa yang senantiasa memiliki motivasi belajar tinggi, melibatkan diri aktif dalam kegiatan belajar, dan memiliki keterlibatan afektif yang tinggi dalam belajar juga dapat dikatakan siswa memiliki motivasi belajar yang tinggi.

\section{Metode Belajar}

Metode merupakan salah satu strategi atau cara yang digunakan oleh guru dalam proses pembelajaran yang hendak dicapai, semakin tepat metode yang digunakan oleh seorang guru maka pembelajaran akan semakin baik. Metode berasal dari kata methodos dalam bahasa Yunani yang berarti cara atau jalan. (Sudjana, 2005) berpendapat bahwa metode merupakan perencanaan secara menyeluruh untuk menyajikan materi pembelajaran bahasa yang teratur, tidak ada suatu bagian yang bertentangan, dan semuanya berdasarkan pada suatu pendekatan tertentu.

\section{Metode Belajar Ceramah Plus}

Metode ceramah plus yaitu metode ceramah gabungan dengan metode lainnya. Metode ini dilakukan secara tertib sesuai dengan urutannya (Trianto, 2010). Dimana biasanya metode ceramah plus adalah metode ceramah yang digabungkan dengan metode diskusi dan pemberian tugas secara teratur. Metode ini sangat umum digunakan di sekolah.

\section{Metode Belajar Discovery Learning}

Menurut (Djamarah, 2008) Discovery Learning adalah belajar mencari dan menemukan sendiri. Dalam sistem belajar mengajar ini guru menyajikan bahan pelajaran yang tidak berbentuk final, tetapi anak didik diberi peluang untuk mencari dan menemukan sendiri dengan menggunakan teknik pendekatan pemecahan masalah. Secara garis besar prosedurnya adalah 1) Simulation. Guru bertanya dengan mengajukan persoalan atau menyuruh peserta didik untuk membaca atau mendengarkan uraian yang memuat permasalahan, 2) Problem statement. Anak didik diberi kesempatan mengidentifikasi berbagai permasalahan, 3) Data 
collection. Untuk menjawab pertanyaan atau membuktikan benar tidaknya hipotesis ini, anak didik diberi kesenpatan untuk mengumpulkan berbagai informasi yang relevan, 4) Data processing. Semua informasi hasil bacaan, wawancara, observasi, dan sebagainya, semua diolah, diacak, diklasifikasikan ditabulasi, bahkan bila perlu dihitung dengan cara tertentu serta ditafsirkan pada tingkat kepercayaan tertentu,5) Verification atau pembuktian. Berdasarkan hasih pemngolahan dan pembuktian, hipotesis yang telah dirumuskan terdahulu kemudian dicek, 6) Generalization. Tahap selanjutnya berdasarkan hasil verifikasi tadi, anak didik belajar menarik kesimpulan.

Pemecahan masalah adalah metode yang mengharuskan pelajar untuk menemukan jawabanya (discovery) tanpa bantuan khusus. Dengan pemecahan masalah pelajar menemukan aturan baru yang lebuh tinggi tarafnya sekalipun ia mungkin tidak dapat merumuskan secara verbal. Salah satu metode belajar yang akhir-akhir ini banyak digunakan di sekolah-sekolah yang sudah maju adalah metode discovery. Hal ini disebabkan karena metode ini merupakan suatu cara untuk mengembangkan cara belajar siswa aktif; Dengan menemukan dan menyelidiki sendiri konsep yang dipelajari, maka hasil yang diperoleh akan tahan lama dalam ingatan dan tidak mudah dilupakan siswa; Pengertian yang ditemukan sendiri merupakan pengertian yang betul-betul dikuasai dan mudah digunakan atau ditransfer dalam situasi lain; anak belajar menguasai salah satu metode ilmiah yang akan dapat dikembangkan sendiri; dan siswa belajar berpikir analisis dan mencoba memecahkan problema yang dihadapi sendiri, kebiasaan ini akan ditransfer dalam kehidupan nyata.

\section{Hasil Analisis Komparatif Metode Ceramah Plus dan Discovery Learning}

Berdasarkan hasil penelitian untuk menjawab tujuan pertama mengenai perbedaan motivasi belajar menggunakan metode pembelajaran Ceramah Plus dan metode pembelajaran Discovery Learning terhadap hasil belajar peserta didik, keaktifan peserta didik dalam bertanya, pengumpulan tugas peserta didik dan kehadiran peserta didik dalam belajar pada saat PJJ. Didapatkan pada taraf signifikansi 0,05 diperoleh bahwa terdapat perbedaan hasil nilai ulangan antara peserta didik yang diajarkan dengan Discovery Learning dibandingkan dengan peserta didik yang diajarkan dengan Ceramah Plus dimana level signifikansi $(0,001)$ lebih kecil dari $\alpha(0,05)$, terdapat perbedaan kehadiran dimana level signifikansi $(0,000)$ lebih kecil dari $\alpha(0,05)$, terdapat perbedaan keaktifan bertanya dimana level signifikansi $(0,000)$ lebih kecil dari $\alpha(0,05)$, dan terdapat perbedaan pengumpulan tugas dimana level signifikansi $(0,31)$ lebih kecil dari $\alpha(0,05)$.

Tabel 1. Hasil Analisis Komparatif

\begin{tabular}{|c|c|c|}
\hline No. & Indikator & $\begin{array}{l}\text { Signifikansi Metode } \\
\text { Discovery Learning - } \\
\text { Ceramah Plus }\end{array}$ \\
\hline 1. & Nilai Ulangan & 0,001 \\
\hline 2. & Daftar Kehadiran & 0,000 \\
\hline 3. & Keaktifan Bertanya & 0,000 \\
\hline 4. & Pengumpulan Tugas & 0,031 \\
\hline
\end{tabular}


Dari hasil uji statistik terhadap keempat nilai diatas, dapat disimpulkan bahwa nilai $\mathrm{H}_{0}<0,05$ yang berarti bahwa terdapat perbedaan dari metode pembelaran ceramah plus dengan metode discovery learning terhadap nilai ulangan, daftar kehadiran, keaktifan bertanya dan pengumpulan tugas.

\section{Hasil Analisis Deskriptif}

Untuk menjawab tujuan kedua mengenai efektifitas metode yang digunakan untuk meningkatkan motivasi belajar peserta didik pada saat PJJ, didapatkan data sebagai berikut:

Tabel 2. Hasil Rata-rata Nilai Efektifitas Metode Ceramah Plus - Discovery Learning

\begin{tabular}{|l|c|c|}
\hline \multirow{2}{*}{\multicolumn{1}{|c|}{ Indikator }} & \multicolumn{2}{|c|}{ Rata-rata nilai (\%) } \\
\cline { 2 - 3 } & Ceramah Plus & Discovery Learning \\
\hline Nilai ulangan & 76,6 & 83,8 \\
\hline Daftar kehadiran & 11,8 & 11,6 \\
\hline Keaktifan bertanya & 2,64 & 0,5 \\
\hline Pengumpulan tugas & 2,8 & 2,9 \\
\hline
\end{tabular}

Dari hasil data statistik diatas, analisis mengenai perbedaan efektifitas metode ceramah plus dengan metode discovery learning terhadap meningkatnya motivasi belajar sebagai berikut:

\section{Ceramah Plus}

Keaktifan bertanya

Daftar Kehadiran

Discovery Learning Nilai Ulangan

\begin{abstract}
Alasan
Peserta didik akan lebih banyak bertanya jika seorang guru memberikan stimulus materi, kemudian membuka ruang diskusi dan hal tersebut merupakan alur metode pembelajaran pada ceramah plus. Sedangkan, jika diberikan bahan materi yang belum final atau dibiarkan mencari jawaban sendiri, peserta didik akan lebih langsung menemukan jawaban dari masalah yang berkaitan dengan pertanyaan secara mandiri dari platform media lain, diluar dari penjelasan guru yang bersangkutan. (discovery learning).
\end{abstract}

Peserta didik akan lebih banyak hadir di ruang kelas jika guru secara penuh memberikan bahan ajar hanya di ruang kelas, sehingga murid menjadi takut ketinggalan materi pelajaran. Sedangkan pada metode discovery learning, guru dan peserta didik tidak wajib berada di dalam ruangan kelas secara bersamaan dengan waktu yang lama, karena materi tersebut bisa dimodifikasi oleh guru dengan menggunakan platform lain seperti google classroom.

\section{Alasan}

Peserta didik sangat diberi keluasan untuk mencari tambahan ilmu dari sumber manapun dalam jangka waktu yang cukup lama, karena guru tidak memberikan materi secara final. Materi yang tidak final, akan memicu peserta didik untuk mencari tahu jawaban dibanyak sumber. Dengan mencari tahu sendiri, peserta didik akan lebih mampu memahami materi, dan memudahkan peserta didik untuk menjawab soal ulangan yang diberikan. 
Pengumpulan Tugas Peserta didik yang mengumpulkan tugas dengan metode discovery learning akan lebih banyak dikarenakan, tugas yang diberikan lebih variatif, serta tugas yang diberikan lebih memacu peserta didik untuk menganalisis suatu masalah yang berkaitan langsung dengan kehidupan sehari-hari. Sehingga membuat peserta didik lebih senang mengerjakan tugas yang bersifat demikian dibandingkan dengan tugas yang hanya menjawab soal yang ada di buku-buku materi yang telah diberikan oleh guru.

Untuk menjawab tujuan ketiga, yakni analisis strategi metode pembelajaran dalam meningkatkan motivasi belajar peserta didik saat PJJ, maka metode pembelaran yang paling baik digunakan adalah discovery learning. Hal ini dikarenakan berangkat dari hasil pengamatan yang ada bahwa: 1) Kendala yang banyak dialami oleh peserta didik saat PJJ adalah masalah fasilitas pendukung seperti koneksi internet dan kerusakan pada perangkat keras pendukung (komputer atau laptop), sehingga pengukuran kedisiplinan pada poin kehadiran sangatlah tidak dapat digunakan pada saat jam kelas sedang berlangsung 2) PJJ sangat berdampak pada sisi psikologis peserta didik, kebosanan belajar dari rumah membuat peserta didik menjadi malas berbicara, sehingga pengukuran keaktifan bertanya juga tidak dapat digunakan dalam motivasi belajar saat PJJ, 3) PJJ membuat guru dan peserta didik tidak dapat bertatap muka sehingga pengawasan terhadap keseriusan belajar peserta didik tidak dapat berjalan secara maksimal, 3) PJJ telah mengubah banyak agenda sekolah yang telah ditetapkan oleh sekolah pada awal tahun ajaran, sehingga jadwal kegiatan belajar mengajar disesuaikan atau lebih fleksibel.

Hal tersebut menjadikan tujuan pembelajaran di masa PJJ lebih melihat kepada aspek kognitif sebagai hasil. Oleh karena itu nilai hasil ulangan dan pengumpulan tugas sebagai standar yang ditetapkan oleh sekolah masih menjadi acuan kenapa akhirnya menurut penueliti, metode pembelajaran discovery learning merupakan metode yang sangat cocok digunakan pada saat PJJ, karena mampu meningkatkan hasil nilai ulangan dan kedisiplinan peserta didik dalam mengumpulkan tugas.

Dibalik kelebihan metode pembelajaran discovery learning yang digunakan dalam PJJ, terdapat pula kelemahan-kelemahan yang harus menjadi fokus evaluasi pada saat proses kegiatan belajar mengajar, diantaranya sebagai berikut: 1) Metode pembelajaran discovery learning pada PJJ yang memberikan keleluasan anak untuk mencari jawaban, mencari masalah dan solusi terkait materi pebelajaran, jika tidak diawasi secara langsung bisa menimbulkan perbuatan curang yang dilakukan oleh peserta didik seperti mencontek jawaban dari teman atau platform media yang telah tersedia dengan mudah di Internet. 2) Metode pembelajaran discovery learning dapat mengakibatkan peserta didik berpikir acak atau mendapatkan hasil pembelajaran yang multitafsir jika di akhir pembelaran guru tidak menjelaskan kembali kesimpulan serta makna dari materi yang diajarkan, khususnya pada mate pelajaran rumpun sosial.

Oleh karena itu dalam kondisi PJJ terutama pada saat pandemi, faktor ekternal juga sangat membantu dalam meningkatkan motivasi belajar peserta didik seperti pengawasan dan dukungan fasilitas belajar yang memadai dari orang tua, koordinasi antara orang tua dan wali kelas, koordinasi antara wali kelas dan guru pengajar, serta jam kegiatan belajar yang harus disesuaikan dengan kondisi yang ada contohnya seperti pengurangan jam belajar. 


\section{KESIMPULAN DAN SARAN}

\section{Kesimpulan}

Berdasarkan hasil penelitian yang dikemukakan pada bab sebelumnya, disimpulkan bahwa terdapat perbedaan pada motivasi belajar peserta didik dengan menggunakan metode pembelajaran ceramah plus dan metode pembelajaran discovery learning yang meliputi hasil nilai ulangan, keaktifan bertanya, daftar kehadiran dan pengumpulan tugas. Untuk setiap metode pembelajaran memiliki efektifitasnya masing-masing. Seperti metode ceramah plus efektif dalam meningkatkan motivasi belajar yang meliputi keaktifan bertanya dan kehadiran peserta didik, sedangkan discovery learning efektif dalam meningkatkan motivasi belajar yang meliputi nilai ulangan dan pengumpulan tugas.

Sementara dalam kondisi kebijakan PJJ, metode yang paling baik digunakan untuk meningkatkan motivasi belajar siswa adalah metode pembelajaran discovery learning. Dikarenakan metode discovery learning terbukti lebih mampu meningkatkan hasil nilai ulangan dan kedisiplinan dalam mengumpulkan tugas. Dalam kondisi PJJ, tercapaianya tujuan pembelajaran akan sangat bergantung pada aspek kognitif siswa yang dibuktikan dengan capaian nilai peserta didik. Hal ini dikarenakan faktor ekternal seperti kendala koneksi internet, tidak terpenuhinya fasilitas belajar, kebosanan peserta didik yang dituntut harus belajar sendiri, suasana belajar yang jauh dari menyenangkan karena tidak boleh keluar rumah akan mempengaruhi kondisi psikologis dan kesiapan peserta didik dalam belajar sehingga akan sulit mengukur kehadiran peserta didik dan keaktifan dalam bertanya sebagai bagian dari indikator motivasi belajar.

\section{Saran}

Dalam kondisi khusus seperti pandemi, instansi pendidikan harus bisa melakukan inovasiinovasi pembelajaran. Khususnya dalam pelaksanaan metode pembelajaran yang mampu menyesuaikan kondisi agar kegiatan belajar mengajar dapat berjalan dengan baik sehingga tetap mampu mencapai tujuan pembelajaran. Guru sebagai fasilitator langsung harus mampu terus berkreasi dan terus melakukan terobosan inovasi teknologi dalam dunia pendidikan.

\section{DAFTAR PUSTAKA}

Ananta, Syintia Dewi, dkk. (2019). Penerapan Model Discovery Learning Untuk

Meningkatkan Hasil Belajar Matematika Siswa Kelas XI MIA 1 MAN 1

PEKANBARU. Garuda: Jurnal Online Mahasiswa Bidang Keguruan dan Ilmu Pendidikan Vol. 6 Ed. 1

A.M, Sardiman. (2010). Interaksi dan Motivasi Belajar Mengajar. Jakarta: Rajawali Pers

Dalyono, M. (2009). Psikologi Pendidikan. Jakarta: Rineka Cipta.

Dani, R. dkk. (2019). Penerapan Pembelajaran Berbasis Discoveri Learning Melalui Metode Talking Stick Untuk Meningkatkan Pemahaman Konsep Gerak Lurus. Edufisika: Jurnal pendidikan Fisika, Vol. 4 No. 2

Dewi, S.M. Puspita, dkk. (2019). Penerapan Metode Discovery Learning Untuk Meningkatkan Kemampuan Penalaran Logis Peserta Didik. Jurnal Pendidikan dan Pembelajaran Ekonomi Akuntasi, Vol. 5 No. 1

Djamarah, S. B. (2008). Strategi Belajar Mengajar. Bandung: Rineka Cipta

Hamalik, Oemar. (2011). Proses Belajar Mengajar . Jakarta: Bumi Aksara

Hasugian, Halomoan, dkk. (2013). Meningkatkan Hasil Belajar Siswa dalam 
Pembelajaran Matematika dengan Metode Discovery Learning Pada Anak Kelas VI Sekolah Dasar Negeri 02 Sejaruk Param. Jurnal Pendidikan dan Pembelajaran Khatulistiwa Vol. 2 No 9

Hutapea, Lisbeth. (2019). Penerapan Model Pembelajaran Discovery Learning Berbantuan Program Cabri 3D untuk Meningkatkan Hasil Belajar Peserta Didik Materi Pokok Dimensi Tiga. Desimal: Jurnal Matematika, Vol. 2 No 1

Kartikasari, I. (2012). Pengaruh Metode Discovery Learning Terhadap Motivasi dan Hasil Belajar Matematika Siswa Pada Pokok Bahasan Kubus Dan Balok [online]. Tersedia. http://www.iaincirebon.ac.id/ppbkdanbalok/iinkartikasari.Pdf

Khaeruman \& Saleh, Muhammad (2016). Pengaruh Percaya Diri Siswa Terhadap Motivasi Belajar Kelas XI IPS di MA.ASHHABUL MAIMANAH SIDAYU. Saintifika Islamica: Jurnal Kajian Keislaman, Vol. 3 No. 1

Kementerian Kesehatan RI. (2020). Data Covid-19. Jakarta

Mashuri. (2019). Upaya Meningkatan Hasil Belajar Matematika Materi Persamaan Dan Fungsi Kuadrat Melalui Metode Discovery Learning Pada Siswa Kelas X IPA MAN Nagekeo Tahun Pelajaran 2018/2019. Jurnal Ilmiah Mandala Education, Vol. 5 No. 1

Miyarso, Estu. (2018). PDF: Definisi, Sejarah, dan Teori Pendidikan Jarak Jauh. Diambil dari http://estumiyarso.blogs.uny.ac.id/wpcontent/uploads/sites/15751/2018/05/Definisi-sejarah-dan-teori-PJJ.pdf

Muthmainnah, R. Nurul \& Sumarsih (2019). Penerapan Metode Discovery Learning Materi Pola Bilangan Sebagai Upaya Mengurangi Kecemasan Siswa Pada Pelajaran Matematika. FIBON : Jurnal Pendidikan Matematika Vol. 5 No. 2

SE Dinas Pendidikan Provinsi DKI Jakarta N0. 27/SE 2020 Tentang Pembelajaran di Rumah

Sudjana. (2005). Metode Statistika. Bandung : Tarsito

Suhartatik, Endang. (2020). Peningkatan Sikap Disiplin dan Hasil Belajar IPA Materi Sistem Gerak Melalui Metode Discovery Learning Bagi SIswa Kelas VIII. INOPENDAS: Jurnal Ilmiah Kependidikan, Vol 3 No. 1

Sulfemi, Wahyu Bagja. (2019). Penerapan Model Pembelajaran Discovery Learning Meningkatkan Motivasi dan Hasil Belajar Pendidikan Kewarganegaraan. Jurnal Rontal Keilmuan Pancasila dan Kewarganegaraan Vol.5 No 1

Trianto. (2010). Mendesain Model Pembelajaran Inovatif - Progresif. Jakarta: Kencana

Uno, Hamzah B. (2011). Teori Motivasi dan Pengukurannya.: Analisis di Bidang Pendidikan. Jakarta: Bumi Aksara

Usman, Wan, dkk. (2003). Daya Tahan Bangsa. Jakarta: Program Studi Pengkajian Ketahanan Nasional Universitas Indonesia

Utami, Andika Putri. (2019). Pengaruh Model Discovery Learning Terhadap Hasil Belajar Matematika Siswa Kelas Xi Mipa Sman 1 Pariaman. Jurnal Edukasi dan Penelitian Matematika, Vol. 8 No 1

UU Nomor 20 Tahun 2003 tentang Sistem Pendidik Nasional 